\title{
Political Education Appropriations Law on the National Development Plan in Indonesia
}

\author{
Ibnu Elmi A.S. Pelu \\ Lecturer of Law, Faculty of ShariaState Islamic Institute (IAIN) of Palangkaraya Indonesia,
}

\begin{abstract}
Indonesian government law politics in the national education sector is interesting to observe. One is when linked with the political direction of the government in the allocation of national education fund at least $20 \%$ of Revenue Expenditure Budget.This paper reveals the politics of law allocating funds from the national education ground norm to setting national education system. The result says that, the political direction of the Indonesian government to allocate funds for education in the legal construction of the National Development Plan and the National Education System is not yet in favor of the education sector as an instrument in the intellectual life of the nation. It can be seen from Inconsistence arrangement about the government's responsibility to change the direction of national education the responsibility of allocating funds by central or centralized to decentralized politics. Therefore, if it is necessary to go back to ground norm recentralization centralized education budget, because decentralization did not fully provide the best solution, especially in education.
\end{abstract}

Keywords:-law politics, national education system

\section{INTRODUCTION}

Amendments to the Law of 1945 a big impact on national development. One effect of these changes is non-application of the Guidelines (the Guidelines of State Policy) as guidelines for the preparation of national development plans. To change the guidelines, the government formulated the National Planning System are regulated in Law No. 25 of 2004. In Act No. 25 of 2004 is State mandated the government as article 13 paragraph (1) that the government set the Long Term Development Plan national (hereinafter abbreviated RPJPN), Regional Long Term Development Plan (hereinafter abbreviated RPJPD), national Medium Term Development Plan (hereinafter abbreviated RPJMN) and the Medium Term Development Plan (hereinafter abbreviated RPJMD).

RPJPN is a translation of the purpose of establishing the State Governments of Indonesia. These objectives stated in the Preamble of the Constitution of the Republic of Indonesia in 1945 Alenia to 4 which is to protect the people and the country of Indonesia, promote the general welfare, educating the nation and participate in the establishment of world order Based freedom, lasting peace and social justice. This is the lofty ideals of the nation Indonesia in 2005 until the year 2025.

However, to realize the lofty goal is not easy. Various conditions and instability issues popping up in various fields and sectors. Both in socio-cultural and religious life, in economic, political, security and defense field, the field of law and government officials, in the field of human resources management, natural resources and environment, territory and spatial planning, including in the field of education and science.

One of the legal issues in the education sector of the arrangement is to highlight the problem of allocating funds for education. Problem budget allocations for education are certainly related to the efforts and goals of the Republic of Indonesia in the intellectual life of the nation through one gate system are increasing and equity of education.

Law of the Republic of Indonesia number 20 of 2003 on National Education System, Article 49 paragraph (1) has been mentioned that the funding of education in addition to salaries of educators and service education costs are allocated at least $20 \%$ of the state budget and at least $20 \%$ of the budget. However, since its promulgation in 2003 up to the year 2012, various problems in the field of education is still found. The problem is the uneven implementation of the budget in the allocation of funds for education $20 \%$ between Higher Education and Education Middle School down the uneven implementation of the budget of Higher Education under the Ministry of National Education Higher Education Religion under the auspices of the Ministry of Religious Affairs, and the uneven implementation of education budget $20 \%$ between the central and regional.

The budget allocation policy between the central and local level, the gap when autonomy is enforced. Precisely what happens is a structured transfer of the budgetary burden to the regions. Perhaps this is not a problem, if the area is an area with high revenue, but what about the areas that are still lagging behind. Meanwhile, the ratio between the number of Secondary School Education institutions down (public/private) in 
Higher Education (public/private) far more Secondary School Education institutions down (SMA/SMK, secondary, and SD). Higher Education fewer depend directly vertically, with the allocation of education funds from the state budget, while the Secondary Education institutions down much more in the area depend on the allocation of funds from the education budget. Of course, an indication of unfairness in allocating education budget by at least $20 \%$ is due to the "jargon" of regional autonomy. So if you see a reflection of the politics of law on decentralization of authority, it was not all good if left to the respective areas. Therefore, especially for education should remain dependent vertically, as many universities. Anis Baswedan, once stated that every year raw input about 5 million primary school children, but the high school graduation only 2 million children. That is, 3 million Indonesian children drop out in the middle of the road. Hence, the legal political reflection direction in RPJPN education sector should prioritize fair treatment and serious in resolving the political problems of education budget down to the middle school.

As a result, the policy to divide the budget burden between the state and local budgets are not proportionate and budget status of Higher Education under the Ministry of Religion that is what needs to be studied more in depth, given the objectives to be achieved by the enactment of Law No. 17 of 2007 on RPJPN $2005-2025$ is the creation of communities are protected, prosperous, intelligent and fair. Therefore, based on the legal issues, the writer is intended to identify legal political funding allocation of national education in Law No. 17 of 2007 in the legal system in Indonesia. Principal issues and then detailed with the effort of finding what the will and the background of the government enacted Law No. 17 of 2007, how a reflection of the politics of law Act No. 17 of 2007 the sector of education in the perspective of the politics of law and the legal system in Indonesia, as well as how effective the purpose of law enactment of Law No. 17 of 2007 in the legal system in Indonesia.

\section{THEORETICAL FRAMEWORK}

The theory is very necessary to dissect document legislation. In this study, the authors apply some theories, law politics, the legal system and legal purposes.

To dissect the configuration of political reflection of what's behind the birth of Law No. 17 of 2007, the author uses the political theory of law. By this theory, the authors attempt to observe the phenomenon of social and political dynamics both before, are and will happen after the enactment of Law No. 17 of 2007, both in terms of the philosophical, sociological, and juridical. So it is necessary to build a new law governing the National RPJP.

Whereas, to analyze the legal political reflection RPJP National education sector, the authors use the political theory of law and the legal system. The political theory of law, the terminology, often termed the politics of law, legal policy, politics of legislation, politics of a legal product and the politics of legal development. Legal politics according to Mohammad Mahfud MD is a legal policy that includes the dynamic development of the law in order to remain relevant, the implementation of the legal form of the assignment of functions of the judiciary and law enforcement training. In addition to the political theory of law, one of the factors the run of the rule of law, due to the run of the legal system. According to Friedman, the legal system consists of three (3) elements, namely: legal materials, legal structure, and culture/legal culture. First, the material elements of the law are used as an attempt to assess whether the material law in Act No. 17 of 2007 has been very clear or they need reassessment. Without good legal matter it can lead to the interpretation or interpretation so that the law can deviate substantially online. Secondly, the element of legal structures such as the police, prosecutors, lawyers and judges (chess dynasty) must perform its function as in the Act and other regulations, because the agency is potential for damage and enforce the law itself. Third, in addition to legal materials and legal structure of the society as part of the legal system, plays an important role in keeping the rules prevailing in society, namely through legal culture. The application of the theory of proper legal system will produce appropriate legal goal of the rule of law, justice and expediency. When the law is going according to the purpose of law, then the law itself will give positive values that can lead to tranquility in society. So that in turn the people will return to believe in the law and can be grounded in the midst of society benefit. This is the true function of the law, which makes the law as a tool in the welfare of a just and prosperous society.

Meanwhile, to analyze how the effectiveness of the objective of the law enactment of Law No. 17 of 2007 on the National RPJP particularly in the education sector in the Indonesian legal system, the authors apply the theories of legal purposes. These theories are ethical theory, theory and normative theory benefitdogmatic/middle way/combination. In theory the ethical, legal purposes solely to achieve justice. According to this theory, the legal content should be determined solely by human ethical awareness, of what is fair and what is unfair. ${ }^{1}$ According Ulpianus, justice is fixed and eternal willingness to give everyone what they deserve. This theory was first proposed by the Greek philosopher Aristotle in his "Ethica Nicomachea" and "Rhetorica" say the law has a sacred duty which gives to every person who is entitled to receive it. ${ }^{2}$ While in theory the benefits,

\footnotetext{
${ }^{1}$ Van Apeldoorn, 1996. Introduction to Law. Jakarta, Pradnya Paramita, p. 12.

${ }^{2}$ Riduan Syahrani, 1999. Summary Highlights Legal Studies. Bandung, Citra Aditya Bakti, p. 20. 
the law aims at realizing solely what is beneficial for others. The originator of this theory is Jeremy Bentham in his book entitled "Introduction to the morals and legislation". According to this theory, the purpose of the law is to ensure their usefulness or happiness as much on people as much as possible (The greatest happiness for the greatest number). What are formulated by Bentham are just notice things that are worthwhile and not expensive about concrete things. It is hard for us to accept this assumption Bentham as pointed out above, that what is expedient was not necessarily meet the values of justice, or in other words, which is useful if more will be found then he would shift the values of justice, and vice versa. To bridge these problems, it is necessary merger theory. The theory is the theory of normative-dogmatic / middle way / combination. According to this theory, the purpose of the law is solely to create legal certainty. Meaning of legal certainty is the certainty legalizes their rights and obligations. The character of this theory that Van Apeldoorn, Bellefroid and Schrassert. ${ }^{3}$

\section{BACKGROUND THE ENACTMENT OF ACT NO. 17 OF 2007 ON THE NATIONAL RPJP IN INDONESIA}

Long-term national development plan is a document of national establishment plan which is a derived from the purpose of establishing the government of the Republic of Indonesia. It is stated in the preamble of the Constitution of the Republic of Indonesia in 1945 in the form of a vision, mission and future direction of development TNI, for the next 20 years covering the period from 2005 to 2025. The National Development Planning is a necessity in a country, Therefore, the State should formulate development planning becomes even make a provision of the Act. Determination Act and documents RPJP National in charge in order to provide direction as well as a reference for all components of the nation in realizing the ideals and national objectives so that all the efforts made by development actors are synergistic, coordinated, and complementary to one another in a pattern of attitudes and patterns of action. ${ }^{4}$

However, to realize the lofty goal is not easy. Various conditions and instability issues popping up in various fields and sectors. Both in socio-cultural and religious life are torn apart by the presence of horizontal conflicts nuances SARA and others. In the field of economics, still the prevalence of food insecurity, unemployment and a lack of educated banking intermediation (CSR) as well as the increasing number of people are near poor. In the field of education and science is still weak even distribution of education funds despite being given a budget of $20 \%$. In politics, still overlapping laws and regulations, the implementation of regional autonomy disproportionate result in the unequal distribution of revenues between the central government and the regions, the weakness of the commission, and there are still many people who do not obtain letters of administration of population and others, In the field of defense and security, the weakness of the border defense system and defense equipment. In the field of legal and government officials, rampant criminal acts of bribery and corruption are widespread; there are still many legal vacuums in various fields. In the management of natural resources and the environment, it seems there are still many conflicts in the region due to the expansion of oil palm plantation project and expropriation of indigenous forests. Field area and layout, unfinished business RTRWP settlement.

Problems and issues laws, the more alarming when 20 years looked to come. On that basis, the government is necessary to prepare and reorganize national development in the form of the Act as the legal basis. Act is what will be the guardian and the benchmark action in a planned long-term development in Indonesia. While the foundation of his philosophy is the spirit toward the biggest fundamental change that is not used Outlines of State Policy of the New Order legacy as a source of National Development Planning System. This is the background changes and the steps the government strategic plan in 2007 and in previous years, thus giving birth to Act No. 17 of 2007 on the National RPJP.

\section{POLITICAL REFLECTION OF LEGAL EDUCATION IN NATIONAL RPJP}

National RPJP vision that Indonesia is an independent, progressive, just and prosperous. In this vision of national development pursued through 8 missions of national development is to create a society that has high morals, ethics, culture, and based on the philosophy of Pancasila, realizing the nation's competitiveness, democratic society based on law, realizing Indonesia secure peaceful and united, embodying equitable development and fair, beautiful and sustainable realize Indonesia, Indonesia became the State realize Islandsindependent, advanced, powerful and based on national interests and realizing Indonesia plays an important role in the international community.

8 of the vision and mission of national development above, which is interesting to study and reread is unclear and yet he said the government in realizing the mission and educating the nation. Mission of the government to achieve the nation's competitiveness as set forth in the National RPJP document may have already touched on the importance of education as an instrument in the intellectual life of the nation. But the

\footnotetext{
${ }^{3}$ Riduan Syahrani, p. 18-19.

${ }^{4}$ Act No. 17 of 2007 on National and Document RPJP RPJP National Chapter I Number 1.3.

\begin{tabular}{llr|}
\hline DOI: $10.9790 / 0837-2109065660$ & www.iosrjournals.org & $58 \mid$ Page
\end{tabular}
}


indecision of government in the development of quality human resources is not matched by political sufficient budget in the National RPJP document. This was evidence that the laws of political reflection in the development of national life are still not concrete. ${ }^{5}$

Viewed from the side of a substance / material law, it seems clear that the National RPJP still not been able to translate that goal laws of the Republic of Indonesia in the intellectual life of the nation. The Law of the Republic of Indonesia Number 12 of 2004 on the financial balance between the central government and local governments are still overlapping and has not been able to resist the arrogance culture/legal culture of the elite at the national level. In addition, if the terms of the substance of the law, there has been no fundamental change regarding the meaning of "national life". The obscurity of meaning, led increasingly arrogant government, especially the Ministry of National Education has not expressly embodies one roof system of national education and national education system.

As a result, starting proportionality curriculum policies, bureaucratic, institutional, accredited until the budget is increasingly unclear. Examples of the budget politics, the Law of the Republic of Indonesia Number 20 of 2003 on National Education System, Article 49 paragraph (1) has been mentioned that the funding of education in addition to salaries of educators and fees service education is allocated at least $20 \%$ of the state budget and at least $20 \%$ of the budget, However, since its promulgation in 2003 up to the year 2012, various problems in the field of education is still found. The problem is the uneven implementation of the budget in the allocation of funds for education $20 \%$ between Higher Education and Education Middle School down the uneven implementation of the budget of Higher Education under the Ministry of National Education Higher Education Religion under the auspices of the Ministry of Religious Affairs, and the uneven implementation of education budget $20 \%$ between centrally and locally.

The budget allocation policy between the central and local level, the gap when autonomy is enforced. Precisely what happens is a structured transfer of the budgetary burden to the regions. Perhaps this is not a problem, if the area is an area with high revenue, but what about the areas that are still lagging behind. Meanwhile, the ratio between the number of Secondary School Education institutions down (public/private) in Higher Education (public / private) far more Secondary School Education institutions down (SMA/SMK, secondary, and SD). Higher Education fewer depend directly vertically, with the allocation of education funds from the state budget, while the Secondary Education institutions down much more in the area depend on the allocation of funds from the education budget. Of course, an indication of unfairness in allocating education budget by at least $20 \%$ is due to the "jargon" of regional autonomy. ${ }^{6}$ So if you see a reflection of the politics of law on decentralization of authority, it was not all good if left to the respective areas. ${ }^{7}$ Therefore, especially for education should remain dependent vertically, as many universities. Hence, the legal political reflection direction in RPJPN education sector should prioritize fair treatment and serious in resolving the political problems of education budget down to the middle school.

\section{V. $\quad$ EFFECTIVENESS OF INTEREST LAW ENACTMENT OF ACT NO. 17 OF 2007 ON THE NATIONAL RPJP THE SECTOR OF EDUCATION}

Interest enactment of Law No. 17 of 2007 on the National RPJP, is justice in society, realizing the great benefits and legally fill the legal vacuum in creating legal certainty after the replacement of the Guidelines. In the context of education, the position of the largest an educational philosophy is that education is a right of every citizen. Not only that, education is a primary need for every citizen. Political reflection law in Act No. 17 of 2007 on the National RPJP are still far from the values of justice, the practical benefits and do not have legal certainty. Justice according to Aristotle is divided into two, first, the theory of distributive justice that justice gives to each person according to ration services. That is, the justice did not demand that everyone gets the same

\footnotetext{
${ }^{5} 2$ Mission to national development is to realize the nation's competitiveness. The ability to high competitiveness is the key to achieving progress and prosperity of the nation. High competitiveness will make Indonesia ready to face the challenges of globalization and were able to take advantage of existing opportunities. To strengthen the competitiveness of the nation, national development in the long term be directed to: a) promote the development of human resources quality and competitiveness, b) strengthen the domestic economy based on regional advantages, c) improve the control, utilization and creation of knowledge, d) build advanced infra-structure, and e) undertake reforms in the law and the State apparatus.

${ }^{6}$ See: Law No. 32 of 2004 Jo. Act No. 12 of 2008 on Regional Government. Additionally see Moh. Mahfud MD, Political Building Law Enforcing the Constitution, LP3ES, Jakarta, 2008, p. 221, namely the famous general proposition about the importance of "Autonomy" is a manifestation of Lord Acton that "Power tends to corrupt and absolute power corrupts absolutely," which means "the power of Absolute Power Tends to Corrupt and Centralized Corrupt in Absolut". With this proposition, regional autonomy as if the God cannot be wrong.

${ }^{7}$ The theory of separation of powers adheres to the basic principles of democratic state that is always demanding and requires the distribution of power, so that power is not concentrated in one hand. Power centered in one hand, contrary to the principles of democracy because it opens up opportunities for arbitrariness and corruption. View Hasbi Abdul Latif and Ali, Politics, Law, Sinar Grafika, Jakarta. 2010, p. 93.
}

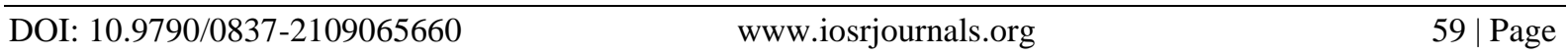


part number or not the similarities, but proportionality based on achievement and merit of a person. Second, the theory of justice cumulative, i.e. justice gives to each person the same ration without considering the number of services each. This means that the law requires an equation in obtaining achievement or something regardless of their respective services. Justice in the context of education, should be provided to all citizens of Indonesia both quantity and quality. But what happens to this day, the fact alignments education for the rich still dominate.

From the aspect of benefits, education is a vehicle and the vital organs in the intellectual life of the nation. Therefore, an understanding of the importance of education is a basic requirement (need dharuriyyat) in legal purposes. So that the position of education equivalent to the primary needs such as food, clothing, shelter, health and safety. To towards the realization of the educational goals, it is necessary to enforce the rule of law and political reviewing the budget and controlling the application of the system of the National RPJP through RPJM first stage.

\section{CONCLUSION}

Based on the results of the discussion, it was concluded some important points in this paper are as follows:First, the occurrence of trans-ideological and madhab law by the government, on the implementation and use of the Guidelines as a guide and instrument of national development, changing uses Openness terjabar National Development Planning in Law No. 17 of 2007.Second, changing ideologies and madhab national development through Act No. 17 of 2007, the general had not fully reflect the harmony between the substance of the law even against groundnorm opening of the Constitution of the Republic of Indonesia in 1945 passage to the 4th and Pancasila. Additionally Law No. 17 of 2007 and the national education system, it was not in favor of the education sector as an instrument in the intellectual life of the nation. It can be seen from two things: first, a reflection of the political separation of legal political authority for the allocation of budget funds education not satisfy the justice of the allocation of funds for education of at least $20 \%$ of state and local budgets. Second, it can be seen from the inconsistency of the norm of the responsibility for allocating funds between groundnorm by setting national education system. In groundnorm mentioned that education is the responsibility of government, but in derivatives on setting national education stated that education is the responsibility of the government, the public and others. Inskonsistensi indicates that the norm of political reflection of the national education law in Indonesia is still biased political regime which adheres to the two political regimes centralized and decentralized political regime. Therefore, if it is necessary to go back to groundnorm recentralisation centralized education budget, because decentralization did not fully provide the best solution, especially in education.Third, the effectiveness of the enactment of Law No. 17 of 2007 does not fully reflect legal politics according to the purpose of the law. This is evidenced, with the government's treatment of the position of education is not something crucial and fundamental.

\section{Book/Journal/Papers/Handout}

\section{REFERENCES}

[1] Apeldoorn, Van. 1996. Introduction to Law. Jakarta, Pradnya Paramita.

[2] Friedman, Lawrence M., 1975. The Legal System: Social Science Perspective. New York, Russell Sage Foundation.

[3] Latif, Abdul dan Hasbi Ali, 2010. Law politics, Sinar Grafika, Jakarta.

[4] Mahfud MD, Moh. 1998. Political Law in Indonesia. First edition, Jakarta, LP3ES.

[5] Mahfud MD, Moh. 2008. Build Political Law Enforcing the Constitution, LP3ES, Jakarta.

[6] Nyoman, I Nyoman. 2012. Hand Out Politics Law Course in Creative New Student Enrichment Program Doctoral Program of UB Law.

[7] Syahrani, Riduan. 1999. Summary Highlights Legal Studies. Bandung, Citra Aditya Bakti.

\section{Legislation}

[1] Constitution of the Republic of Indonesia Year 1945.

[2] Act No. 25 of 2004 on National Development Planning System.

[3] Law No. 17 Year 2007 on the National RPJP and National RPJP Document 2005-2025.

[4] Act No. 33 of 2004 on Financial Balance between the Central Government and Local Government.

[5] Law No. 20 Year 2003 on National Education System.

[6] Act No. 32 of 2004 on Regional Government.

[7] Law No. 12 Year 2008 regarding the Second Amendment to Law Number 32 Year 2004 on Regional Government. 